\title{
A CLINICO- HEMATOLOGICAL STUDY IN CASES OF PANCYTOPENIA: CORRELATION OF AUTOMATED CELL COUNTER PARAMETERS IN VARIOUS ETIOLOGIES
}

Soma Yadav¹, Rashmi Kushwaha², Kamal Aggrawal3 , A.K Tripathi', U.S Singh ${ }^{5}$, Ashutosh Kumar6.

1. Junior Resident, Department. Of pathology, King George's Medical University

2. Assistant Professor, Department. Of pathology, King George's Medical University

3. Professor, Department. Of pathology, King George's Medical University

4. Professor and Head, Department. Of Clinical Hematology, King George's Medical University

5. Professor, Department. Of pathology, King George's Medical University

6. Professor and officer in charge, Lymphoma- Leukemia Lab, Department. Of pathology, King George's Medical University.

\section{CORRESPONDING AUTHOR:}

Dr. Rashmi Kushwaha,

King George's Medical University,

Lucknow.

E-mail: docrashmi27@yahoo.co.in

ABSTRACT: BACKGROUND: Pancytopenia is an important clinico-haematological entity encountered in our day to day clinical practice. It is defined as the reduction of all three formed elements of blood (erythrocytes, leucocytes and platelets) below the normal reference range leading to anaemia, leucopoenia and thrombocytopenia. OBJECTIVES: To study the etiologies, to assess the haematological and bone marrow changes and to correlate these changes with automated cell counter parameters in various causes of pancytopenia. Assessment of B12 and folic acid levels in cases of pancytopenia due to megaloblastic anemia. MATERIAL METHODS: It was a prospective study; all pancytopenic patients were evaluated clinically, along with automated cell counter parameters, bone marrow aspiration and trephine biopsies in Department of Pathology, K.G.M.U, Lucknow from July 2011 to July 2012.RESULTS: Among 60 cases studied, maximum number of patients were in first decade of life. Most important cause of pancytopenia was aplastic anemia. Significant lymphocytosis was associated with aplastic anemia compared to other causes of pancytopenia. RDW-CV and Mean platelet volume is significantly increased in pancytopenia due megaloblastic anemia as compared to other causes of pancytopenia CONCLUSION: Pancytopenia is a common haematological problem encountered in clinical practice and should be suspected on clinical grounds when a patient presents with unexplained anaemia, prolonged fever and tendency to bleed. The present study concludes that detailed primary haematological investigations along with bone marrow aspiration in cytopenic patients are helpful for understanding the disease process to diagnose, or to rule out the causes of cytopenia, and in planning further investigations and management of cytopenic patients.

INTRODUCTION: Pancytopenia is an important clinico-hematological entity encountered in our day to day clinical practice. It is defined as the reduction of all three formed elements of blood (erythrocytes, leucocytes and platelets) below the normal reference range leading to anemia, leucopenia, thrombocytopenia(1) Pancytopenia is not a disease entity but a triad of findings that 
may result from a number of disease processes. Variety of disorders, hematological and nonhematological can affect the bone marrow primarily or secondarily, resulting in the manifestation of pancytopenia.(2) The presenting symptom are usually attributable to anemia or thrombocytopenia, leucopenia is an uncommon presentation and can become the most serious threat to life during the course of disorder. Patient with pancytopenia present with different clinical features. A patient with anemia usually presents with pallor, malaise, and associated symptoms such as palpitations and dyspnea. Patient with thrombocytopenia present with easy bruising, gum bleeding and petechiae, patients with leucopenia present mostly with recurrent history of infections ${ }^{1,3}$. Early diagnosis of various causes of pancytopenia is very crucial and requires prompt clinical examination and investigations like complete blood count, peripheral smear and bone marrow examination as marrow cellularity and composition in cases of pancytopenia differ in relationship to underlying pathologic conditions. The marrow is generally hypocellular in cases of pancytopenia caused by a primary production defect. Cytopenias resulting from ineffective hematopoiesis, increased peripheral utilization or destruction of cells, and bone marrow invasive processes are usually associated with a normo cellular or hyper cellular marrow.

Therefore bone marrow examinations such as bone marrow aspiration and biopsy are extremely helpful in evaluating the cause of pancytopenia in order to prevent grave complications and mortality as the underlying pathology determines the management and prognosis of the patients 4 .

This study therefore aims at establishing a correlation between clinical history, examination of peripheral blood finding, biochemical findings and bone marrow findings along with an analysis of automated cell counter parameters that can be of help in analyzing the possible causes of pancytopenia and thereby will automatically enhance the management process.

MATERIAL AND METHOD: This was a prospective study of one year duration from July 2011 to July 2012. Patients diagnosed as a case of pancytopenia having Hemoglobin less than $10 \mathrm{gm} / \mathrm{dl}$, Total leucocyte countless than4000/cumm, Platelets less than 100,000/cu. mm. were taken in the study.

STATISTICAL ANALYSIS: Continuous data were summarized as Mean \pm SD while discrete (categorical) in \%. The groups were compared by one way analysis of variance (ANOVA) followed by Tukey's post hoc test after ascertaining the normality by Shapiro-Wilk test and the homogeneity of variance by Levene's test. The categorical variables were compared by chi-square $\left(\chi^{2}\right)$ test. Pearson correlation analysis was used to assess association between the variables. A two-sided $(\alpha=2) p<0.05$ was considered statistically significant. All analyses were performed on STATISTICA (window version 6.0).

RESULTS: The present study was carried out in the Department of Pathology, in a medical institute, to study the underlying etiology in patients presenting with pancytopenia. A total of 60 cases presenting with pancytopenia were enrolled in the study.

Most of the patients belong to lower age ( $\leq 30 \mathrm{yrs}$ ) groups $(73.30 \%)$ with maximum number of patients were $\leq 10$ yrs $(30.0 \%$ ) (figure 1 ). Male to female ratio was 1:1.2.

Most common etiology of pancytopenia was Aplastic anemia (38.3\%), Megaloblastic anemia (21.7\%) and Acute leukemia (13.3\%), minor causes being Myelodysplastic syndrome, Hypersplenism, Non-Hodgkin's lymphoma, Leishmaniasis, Metastatic infiltration, HIV disease, Hemolytic anemia and Drug induced hypoplasia ( figure 2). 
The most common clinical manifestations were fever $(100 \%)$, pallor $(100 \%)$, and weight loss $(100 \%)$ at the time of enrolment. Less common were neurological (3.2\%), and bleeding from various sites as skin, nose, and gastrointestinal tract. Hepatomegaly (22.7\%), splenomegaly (25\%) and lymphadenopathy (11.7\%) were also seen

Peripheral smear findings are discussed in table 1.

\begin{tabular}{|c|c|c|c|c|c|c|c|}
\hline Diagnosis & n & $\begin{array}{l}\text { Immatur } \\
\text { e } \\
\text { erythroi } \\
\text { d precu- } \\
\text { rsor }\end{array}$ & $\begin{array}{l}\text { Hyperseg } \\
\text { mented } \\
\text { neutrophi } \\
\text { l }\end{array}$ & $\begin{array}{l}\text { Immatu } \\
\text { re } W B C\end{array}$ & $\begin{array}{l}\text { Lympho } \\
\text { cytosis }\end{array}$ & $\begin{array}{l}\text { Increased } \\
\text { reticulocyt } \\
\text { es }\end{array}$ & $\begin{array}{l}\text { Anisopoikilocy } \\
\text { tosis }\end{array}$ \\
\hline $\begin{array}{l}\text { Aplastic } \\
\text { anemia }\end{array}$ & 23 & - & - & - & 21 & - & 4 \\
\hline $\begin{array}{l}\text { Megaloblast } \\
\text { ic anemia }\end{array}$ & 13 & 3 & 5 & - & 9 & 2 & 9 \\
\hline $\begin{array}{l}\text { Acute } \\
\text { leukemia }\end{array}$ & 8 & - & - & 8 & 7 & 1 & 4 \\
\hline $\begin{array}{l}\text { Hypersplen } \\
\text { ism }\end{array}$ & 2 & - & - & - & 2 & - & 1 \\
\hline MDS & 3 & - & - & 1 & 3 & - & 1 \\
\hline $\begin{array}{l}\text { Non- } \\
\text { Hodgkins } \\
\text { lymphoma } \\
\end{array}$ & 3 & 2 & - & 1 & 3 & - & 1 \\
\hline Hepatitis & 2 & - & - & - & 2 & - & 1 \\
\hline $\begin{array}{l}\text { Leishmania } \\
\text { sis }\end{array}$ & 2 & - & - & - & 2 & - & 2 \\
\hline $\begin{array}{l}\text { Hemolytic } \\
\text { anemia }\end{array}$ & 1 & - & - & - & - & 1 & 1 \\
\hline $\begin{array}{l}\text { HIV } \\
\text { associate }\end{array}$ & 1 & - & - & - & 1 & - & 1 \\
\hline $\begin{array}{l}\text { Malignant } \\
\text { infiltration }\end{array}$ & 1 & - & - & - & 1 & - & 1 \\
\hline $\begin{array}{l}\text { Drug } \\
\text { induced }\end{array}$ & 1 & - & - & - & 1 & - & 1 \\
\hline Total & 60 & & & & & & \\
\hline
\end{tabular}

For further analysis, causes of pancytopenia have been grouped into: Aplastic anemia, Megaloblastic anemia, pancytopenia due to Infiltration (which comprises of acute leukemia, NonHodgkin's lymphoma, metastatic infiltration and MDS), pancytopenia due to other causes (all infectious causes- Leishmaniasis, hepatitis, hypersplenism, HIV reactive, and single case of hemolytic anemia and single case of drug induced pancytopenia). 
Patients of aplastic anemia had significant lymphocytosis $(\mathrm{p}<0.05)$ compared to megaloblastic $(76.74 \pm 15.06$ vs $44.62 \pm 20.44, \mathrm{p}=0.000)$, infiltration $(59.07 \pm 26.40, \mathrm{p}=0.043)$, other causes $(44.56 \pm 15.36 \mathrm{p}=0.001)$.

Very low Total Leucocyte Count $(<1000 /$ cu.mm) was seen in Aplastic anemia and infiltration as $\left(\chi^{2}=13.51, p=0.036\right)$ as compared to Megaloblastic anemia(1000-4000/cu.mm).

Lower Platelets counts $(<20,000 /$ cu.mm) significantly $(\mathrm{p}<0.001)$ associated with Aplastic anemia and Infiltration while higher Platelets counts $(>20,000 / \mathrm{cu} . \mathrm{mm})$ with the Megaloblastic anemia $\left(\chi^{2}=29.76, p<0.001\right)$.

The normal $(83-99 \mathrm{fl})$ values of MCV was significantly $(\mathrm{p}<0.001)$ associated with Aplastic anemia and Infiltration while more than $>100 f l$ especially with the Megaloblastic anemia $\left(\chi^{2}=25.39\right.$, $\mathrm{p}<0.001$ ) (table2)

Table 2: Distribution of the MCV in different causes of pancytopenia

\begin{tabular}{|c|c|c|c|c|c|c|}
\hline Diagnosis & $\begin{array}{l}\text { No. of } \\
\text { cases }\end{array}$ & $<83 \mathrm{fl}$ & 83-99fl & $>100 \mathrm{fl}$ & $\begin{array}{l}\chi^{2} \text { value } \\
(\mathrm{DF}=6)\end{array}$ & $\begin{array}{l}p \\
\text { value }\end{array}$ \\
\hline Aplastic anemia & 23 & 4 & 12 & 7 & \multirow{4}{*}{25.39} & \multirow{4}{*}{$\mathrm{p}<0.001$} \\
\hline $\begin{array}{l}\text { Megaloblastic } \\
\text { anemia }\end{array}$ & 13 & 0 & 0 & 13 & & \\
\hline Infiltration & 15 & 5 & 7 & 3 & & \\
\hline Others & 9 & 3 & 1 & 5 & & \\
\hline Total & 60 & 12 & 26 & 22 & & \\
\hline
\end{tabular}

However, no significant difference was found in $\mathrm{MCH}$ and $\mathrm{MCHC}$ values in different causes of pancytopenia.

The normal (11.6-14.0\%) RDW-CV values were significantly $(\mathrm{p}<0.001)$ associated with Aplastic anemia while higher $(>14 \%)$ with the Megaloblastic anemia and Infiltration $\left(\chi^{2}=18.93, p<0.001\right)$ (table 3)

Table 3: Distribution of the RDW-CV in the different causes of pancytopenia

\begin{tabular}{|c|c|c|c|c|c|}
\hline Diagnosis & $\begin{array}{l}\text { No. of } \\
\text { cases }\end{array}$ & $11.6-14 \%$ & $>14 \%$ & $\begin{array}{l}\chi^{2} \text { value } \\
(\mathrm{DF}=3)\end{array}$ & $\begin{array}{l}p \\
\text { value }\end{array}$ \\
\hline Aplastic anemia & 23 & 16 & 7 & \multirow[t]{4}{*}{18.93} & \multirow[t]{4}{*}{$\mathrm{p}<0.001$} \\
\hline Megaloblastic anemia & 13 & 1 & 12 & & \\
\hline Infiltration & 15 & 2 & 13 & & \\
\hline Others & 9 & 3 & 6 & & \\
\hline Total & 60 & 22 & 38 & & \\
\hline
\end{tabular}


The normal values $(6-13 \mathrm{fl})$ of MPV is significantly $(\mathrm{p}<0.001)$ associated with Aplastic anemia, Infiltration and Other causes of pancytopenia while higher $(>13 \%)$ with the Megaloblastic pancytopenia $\left(\chi^{2}=20.25\right.$, $\left.\mathrm{p}<0.001\right)($ table 4$)$

Table 4: Distribution of the MPV in the different causes of pancytopenia

\begin{tabular}{|c|c|c|c|c|c|}
\hline Diagnosis & $\begin{array}{l}\text { No. of } \\
\text { cases }\end{array}$ & 6-13fl & $>13 \mathrm{fl}$ & $\begin{array}{l}\chi^{2} \text { value } \\
(\mathrm{DF}=3)\end{array}$ & $\begin{array}{l}p \\
\text { value }\end{array}$ \\
\hline Aplastic anemia & 23 & 20 & 3 & \multirow{4}{*}{20.25} & \multirow{4}{*}{$\mathrm{p}<0.001$} \\
\hline Megaloblastic anemia & 13 & 4 & 9 & & \\
\hline Infiltration & 15 & 13 & 2 & & \\
\hline Others & 9 & 9 & 0 & & \\
\hline Total & 60 & 46 & 14 & & \\
\hline
\end{tabular}

Bone marrow cellularity is significantly associated with different causes of pancytopenia. Bone Marrow Hypocellularity showed a significant association with Aplastic anemia while both Normocellularity and Hypercellularity showed association with Megaloblastic anemia and Infiltration $\left(\chi^{2}=48.23, \mathrm{p}<0.001\right)$ (table 5)

Table 5: Cellularity in different causes of pancytopenia in the aspiration

\begin{tabular}{|c|c|c|c|c|c|c|}
\hline Diagnosis & $\begin{array}{l}\text { No. of } \\
\text { cases }\end{array}$ & $\begin{array}{l}\text { Hypocellul } \\
\text { ar }\end{array}$ & $\begin{array}{l}\text { Normocellul } \\
\text { ar }\end{array}$ & $\begin{array}{l}\text { Hypercellula } \\
\mathbf{r}\end{array}$ & $\begin{array}{l}\chi^{2} \text { value } \\
(\mathrm{DF}=6)\end{array}$ & $\begin{array}{l}p \\
\text { value }\end{array}$ \\
\hline Aplastic anemia & 23 & 23 & 0 & 0 & \multirow{4}{*}{48.23} & \multirow{4}{*}{$\mathrm{p}<0.001$} \\
\hline $\begin{array}{l}\text { Megaloblastic } \\
\text { anemia }\end{array}$ & 13 & 0 & 6 & 7 & & \\
\hline Infiltration & 15 & 1 & 7 & 7 & & \\
\hline Others & 9 & 3 & 3 & 3 & & \\
\hline Total & 60 & 27 & 16 & 17 & & \\
\hline
\end{tabular}

Five cases were normocellular on aspiration, of which two cases (40\%) turned out to be hypercellular and one (20\%) hypocellular on trephine biopsy $\left(\chi^{2}=23.23, p=0.001\right)$. Of the ten cases that were hypocellular on aspiration, one case showed normo-cellularity on biopsy along with focal bone marrow necrosis. Two cases that could not be aspirated due to dry tap were both hypercellular on biopsy. Thus concluding that bone marrow biopsy allows a better assessment of cellularity in addition to diagnosing the patient with dry tap on aspiration.

B12 and Folate deficiencies assessment were done in 11 out of 13 patients of megaloblastic anemia. Among, Megaloblastic anemia patients, the prevalence of B12 deficiencies was the highest (41.7\%) followed by combined deficiency (25.0\%) (Figure 3). 
DISCUSSION: Our study group consisted of a total of 60 cases diagnosed as pancytopenia having hemoglobin less than $10 \mathrm{gm} \%$, total leucocyte count less than 4000/cu.mm and a platelet count of less than 1,00,000/cumm. As depicted in figure no.1, maximum numbers of cases were upto 10 years of age whereas the second most commonly affected age group was between 11- 20 years (23.3\%). Khunger et al. reported maximum number of cases in the third decade of life (4). Male: female ratio (1:1.2) in our study was almost equal. This was similar to Khunger et al. who reported a M:F ratio of 1.2:1.(4)

As shown in figure 2, on the basis of bone marrow examination the most common cause of pancytopenia in our study was Aplastic anemia (38.3\% of patients). This is in concordance with the study of Varma et al., Kumar et al, Santra et al.(5,6)

Whereas in studies of Khodke et al, Khunger et al, Tilak et al, Premkumar $\mathrm{M}$ et al, and Gayathri et al, megaloblastic anemia was the most important cause of Pancytopenia. $(2,4,7,8)$ In another study by Pine et al., 64 children were identified with diagnosis of pancytopenia. The most common causes were infectious in origin (64\%), followed by hematological (28\%) and miscellaneous (8\%) etiologies.(9)

The Pathophysiology of Aplastic anemia is believed to be immune mediated, with active destruction of blood forming cells by the lymphocytes. The aberrant immune response may be triggered by environmental exposures, such as to chemicals and drugs or viral infections and perhaps endogenous antigens generated by genetically altered bone marrow cells. This underlying mechanism is similar to other human disorders of lymphocyte mediated tissue specific organ destruction (diabetes, multiple sclerosis, colitis etc).

Acute leukemia was noted in $8(13.4 \%)$ cases of pancytopenia in our study. Khunger et al.(4) reported an incidence of 5\%. M. Premkumar et al. (9.2\%) (7), BN Gayathri et al. (3.85\%) (8), compared to Kumar R et al.(12\%).(5) In our study among the eight leukemic patients, five were of ALL subtype. On flow cytometry, four of these leukemic patients were found to be of B cell type and there was a single case of $\mathrm{T}$ cell type leukemia. One case was of undifferentiated type. This patient expired within 4 days of the presentation and flow cytometric analysis was not done on the patient. The other two were cases of AML presenting in adults. On bone marrow aspiration of one of these we got a dry tap in one patient, she was subsequently subjected to biopsy which revealed AML probably arising from MDS, as there was evidence of dysplasia in the hematopoietic cells of the marrow along with the presence of myeloid blasts.

Zhou RH et al. in their article have stated that in case of AML, biopsy specimen will give more information than an aspiration smear about marrow cellularity, infiltration, presence of residual hemopoietic cells, qualitative and quantitative abnormalities of megakaryocytes showing myelodysplastic features.(10)

Thus concluding that bone marrow biopsy allows a better assessment of cellularity in addition to diagnosing the patient with dry tap on aspiration. The pathophysiology of pancytopenia in acute leukemia is unclear but is probably related to a combination of suppression of normal haematopoesis and replacement of bone marrow by leukemic cells resulting in pancytopenia and immunosuppression (11). Pancytopenia with few abnormal cells as seen in Myelodysplastic Syndrome was noted in $5 \%$ of our cases. In the study done by Khunger et al. (4) prevalence of MDS was found to be $2 \%$ similar to Kishor Khodke et al.(2\%).(2) 
MDS is characterized by peripheral pancytopenia despite a normocellular or hypercellular bone marrow because of increased apoptosis of hematopoietic bone marrow resulting in ineffective haematopoesis. Inhibition of apoptotic mechanism may induce leukemic transformation in MDS.(12) Pancytopenia related to Non Hodgkins Lymphoma was noted in 5\% of the patients in our study as compared to the reported prevalence of $1 \%$ by Khunger et al.(4)

Pancytopenia in lymphoma was earlier thought to be due to two mechanisms: 1) Bone marrow infiltration 2) Hypersplenism. However, despite splenomegaly, hypersplenism has no major role in causing the cytopenias. The bone marrow is never sufficiently infiltrated to account for low peripheral blood counts. Evidence suggests that the neoplastic T cells cause suppression of haematopoesis through the lymphokines. Thus the main pathogenetic mechanism of cytopenias is the cell mediated suppression of normal haematopoesis.(13)

Among other causes of Pancytopenia, HIV was the important cause. Virtually all patients with advanced AIDS have pancytopenia as a rule the causes are production of the antibodies which might be triggered by the exposure of crypt antigens as a consequence of infection related damage of blood cells especially platelets and granulocytes. The haematopoietic cells especially platelets and granulocytes are antigenically similar to agents like HIV and other micro-organisms infecting the patients. These antibodies could interact with tissue antigens. Third possibility is that HIV act as the direct inducer of autoimmunity. ${ }^{(14,15)}$

Table 6: Studies on Pancytopenia:

\begin{tabular}{|c|c|c|c|c|c|}
\hline Study & Country & $\begin{array}{l}\text { No. of } \\
\text { cases }\end{array}$ & $\begin{array}{l}\text { Most common } \\
\text { cause }\end{array}$ & $\begin{array}{l}\text { Second common } \\
\text { cause }\end{array}$ & Other causes \\
\hline 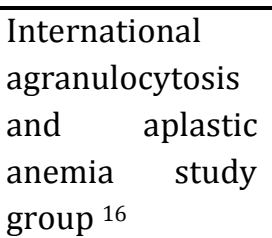 & $\begin{array}{l}\text { Israel } \\
\text { \&Europe } \\
1987\end{array}$ & 319 & AA (52.7\%) & MDS (4.5\%) & $\begin{array}{l}\text { AML, KZ, TB, Storage disease, MM, } \\
\text { Lymphoma }\end{array}$ \\
\hline Keisu and Ost 17 & $\begin{array}{l}\text { Israel \& } \\
\text { Europe } \\
1990\end{array}$ & 100 & $\begin{array}{l}\text { Neoplastic } \\
\text { disease, } \\
\text { radiation } \\
(32 \%)\end{array}$ & AA $(19 \%)$ & $\begin{array}{l}\text { MA, SLE, Drug induced, Falciparum } \\
\text { Malaria, TB, CLL, MM, MDS, PNH,HIV }\end{array}$ \\
\hline Khodke et al. ${ }^{2}$ & $\begin{array}{l}\text { India } \\
2000\end{array}$ & 50 & MA (44\%) & HA (14\%) & $\begin{array}{l}\text { KZ, MM, HIV, MDS, AML, TB, Drug induced } \\
\text { cytopenia. }\end{array}$ \\
\hline Kumar et al. 5 & $\begin{array}{l}\text { India } \\
2001\end{array}$ & 166 & AA $(29.51 \%)$ & MA (22.3\%) & Aleukemic Leukemia, Lymphoma, MDS \\
\hline Khunger et al ${ }^{4}$ & $\begin{array}{l}\text { India } \\
2002\end{array}$ & & MA $(72 \%)$ & AA $(14 \%)$ & $\begin{array}{l}\text { Aleukemic Leukemia, MDS, KZ, NHL, } \\
\text { Malaria, TB, MM, Myelofibrosis }\end{array}$ \\
\hline M. Premkumar ${ }^{7}$ & $\begin{array}{l}\text { India } \\
2008\end{array}$ & 140 & MA (60.7\%) & $\begin{array}{l}\text { Leukemia }(9 \%) \\
\text { AA }(8 \%)\end{array}$ & $\begin{array}{l}\text { HIV, TB, KZ, Malaria, MDS, CML, Gauchers, } \\
\text { Metastatic carcinoma }\end{array}$ \\
\hline Santra et al ${ }^{6}$ & $\begin{array}{l}\text { India } \\
2010\end{array}$ & 111 & AA $(22 \%)$ & $\begin{array}{l}\text { Hypersplenism } \\
(11 \%)\end{array}$ & $\begin{array}{l}\text { MA, SLE, Drug induced, Falciparum } \\
\text { Malaria, TB, CLL, MM, MDS, PNH, HIV }\end{array}$ \\
\hline Gayatri BN et al ${ }^{8}$ & $\begin{array}{l}\text { India } \\
2011\end{array}$ & 104 & MA $(70.04 \%)$ & HA(18.26) & $\begin{array}{l}\text { Subleukemic Leukemia, Malaria, MM, } \\
\text { Storage disorders. }\end{array}$ \\
\hline Present study & $\begin{array}{l}\text { India } \\
2012\end{array}$ & 60 & AA $(38.3 \%)$ & $\begin{array}{l}\text { Megaloblastic } \\
\text { anemia }(21.7 \%)\end{array}$ & $\begin{array}{l}\text { Leukemia, non-Hodgkins lymphoma, } \\
\text { infiltration, MDS }\end{array}$ \\
\hline
\end{tabular}


In our study $23 \%$ and $31 \%$ of the patients with Megaloblastic anemia presented with splenomegaly and hepatomegaly respectively along with two patients $(15.3 \%)$ with lymphadenopathy. Osama Ishtiaq et al. in their study found $15.4 \%$ and $17.9 \%$ of megaloblastic anemia with splenomegaly and hepatomegaly respectively.(18)

As noted in our study as well as in study of Gayathri et al(8) Khunger et al(4) bone marrow lymphocytosis is more in aplastic anemia than Pancytopenia due to other causes.

A significant finding in our study was that the patients of aplastic anemia had a normal Mean Platelet Volume in $87 \%$ of the patients, as compared to megaloblastic anemia which shows higher than normal values in $70 \%$ of the patients as shown in table. Patients with acute leukemia and MDS had normal range. So MPV may be used as a parameter to differentiate megaloblastic pancytopenia from non-megaloblastic pancytopenia. MPV in Megaloblastic Anemia is significantly increased $(\mathrm{p}<0.05)$ as compared to Aplastic Anemia $(13.72 \pm 1.75$ vs $9.18 \pm 2.83, p=0.000)$, infiltration $(10.07 \pm 2.39, \mathrm{p}=0.001)$, and all other causes of pancytopenia $(9.33 \pm 1.21, \mathrm{p}=0.000)$ as shown in figure. This was in concordance with the study done by Chandra $\mathrm{H}$ et al(19).

Similarly Platelet distribution width (PDW) is significantly raised in patients with MDS as compared to all non myelodysplastic causes of pancytopenia.

In our study as well in study done by M Premkumar et al, the most important cause of megaloblastic Pancytopenia was cobalamine deficiency (7). Thus these studies reveal the multifactorial causation of Pancytopenia in our population is probable and occult cobalamine deficiency may contribute to the burden of hematological disease in patients with other primary diagnosis.

CONCLUSION: Pancytopenia is a common haematological problem encountered in clinical practice and should be suspected on clinical grounds when a patient presents with unexplained anaemia, prolonged fever and tendency to bleed. The present study concludes that detailed primary haematological investigations along with bone marrow aspiration, trephine biopsy and biochemical investigations are helpful for understanding the disease process to diagnose, or to rule out the causes of cytopenia, and in planning further investigations and management of cytopenic patients. Proper diagnostic work up is essential before use of hematinics and blood transfusion in all patients presenting as pancytopenia. Limitations of this study include lack of facilities and financial constraints.

\section{REFERENCES:}

1. N. S. Young. Aplastic anemia, myelodysplasia, and related bone marrow failure syndromes. In D. L. Kasper, E. Braunwald, and A. S. Fauci. Harrison's Principles of Internal Medicine,17th edition, United states of America, McGraw Hill,2008;663-671.

2. Khodke K, Marwah S, Buxi G, Vadav RB, Chaturvedi NK. Bone marrow examination in cases of pancytopenia. J Academy Clin Med 2001; 2:55-9.

3. E. C. Guinan and A. Shimamura. Acquired aplastic anemia. In John P. Greer, John Foerster, George M. Rodgers. Wintrobes's Clinical Hematology, 12th edition, Philadelphia, 2004; 1185211. 
4. Khunger JM, Arulselvi S, Sharma U, Ranga S, Talib VH. Pancytopenia-A Clinico-hematological study of 200 cases. Indian J Pathol Microbiol 2002; 45:375-9.

5. Kumar R, Kalra SP, Kumar H, Anand AC, Madan H. Pancytopenia - a six year study. J Assoc Phys India 2001; 49:1078-81.

6. Santra G, Das B K. A cross sectional study of the clinical profile and aetiological spectrum of pancytopenia in a tertiary care centre. Singapore Med J 2010; 51(10):806-12.

7. M. Premkumar, N. Gupta, T. Singh, and T. Velpandian. Cobalamin and Folic Acid Status in Relation to the Etiopathogenesis of Pancytopenia in Adults at a Tertiary Care Centre in North India. Anemia Volume 2012 (2012), Article ID 707402, 12 pages. doi:10.1155/2012/707402.

8. Gayathri BN, Rao KS. Pancytopenia: A clinico hematological study. J Lab Physicians 2011; 3:1520.

9. Pine M, Walter AW. Pancytopenia in hospitalized children: a five-year review. J Pediatr Hematol Oncol. 2010 Jul; 32(5):192-4.

10. Zhou RH, Pu Q, Tang CS.A histopathological study of bone marrow in acute myeloid leukemia. Zhonghua Nei Ke Za Zhi. 1991; 30(9):566- 595.

11. Madhuchanda Kar, Alokendu Ghosh. Pancytopenia. JIACM 2002;3(1):29-3.

12. Shimazaki K, Ohshima K, Suzumiya J, Kawasaki C, Kikuchi M. Evaluation of apoptosis as a prognostic factor in myelodysplastic syndromes.Br J Haematol 2000;110(3):584-90.

13. Linch CD, Goldstone HA, Mason YD. Malignant lymphomas. In Hoffbrand, Lewis, Tuddenham (ed). Postgraduate Haematology.4th edition. Oxford: Butterworth-Heinemann; 1999:479-509.

14. Costello C. Haematological abnormalities in human immunodeficiency virus disease. J clinpathol 1988; 41:711-5.

15. Mosses A, Nelson J, Grover C. The influence of human immunodeficiency virus on haematopoesis. Blood 1998; 92(5):1479-95.

16. Incidence of Aplastic Anemia: The relevance of diagnostic criteria. By the international Agranulocytosis and Aplastic Anemia study. Blood 1987; 70:1718-21.

17. Keisu M, Ost A. Diagnosis in patients with severe Pancytopenia suspected of having aplastic anemia. Eur J Hematol 1990 Jul; 45(1):11-4.

18. Osama I, Haider ZB, Anwer F, Nisar H. Pattern of pancytopenia patients in a general medical ward and a proposed diagnostic approach. J Ayub Med Coll Abbottabad 2004; 16:8-13.

19. Chandra H, Chandra S, Rawat A, Verma SK. Megaloblastic pancytopenia vis-à-vis nonmegaloblastic pancytopenia: is mean platelet volume useful discriminating indicator. Int J Lab Hematol 2011 Aug; 33(4):409-13. 


\section{ORIGINAL ARTICLE}

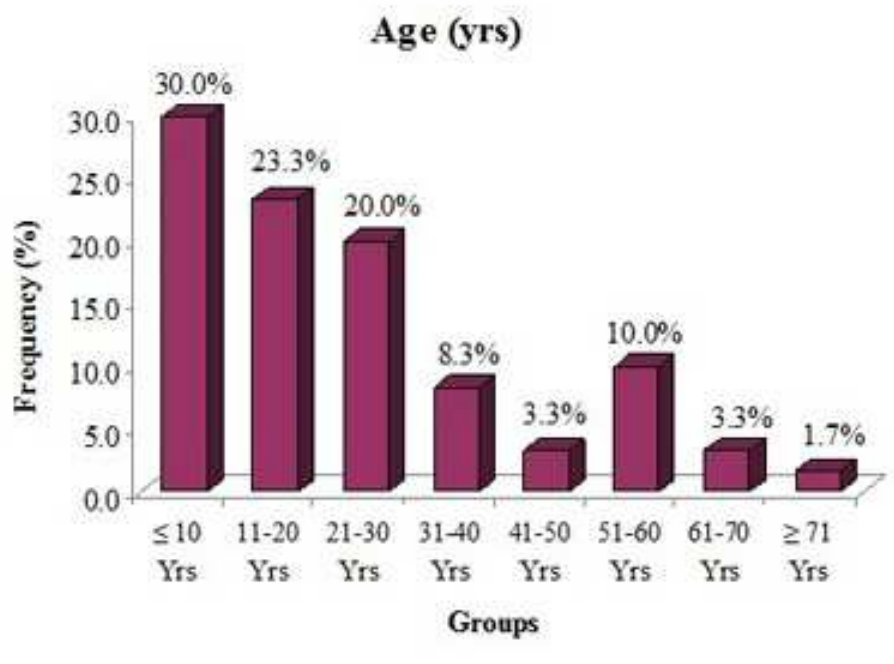

Fig. 1: Age distribution of cases with pancytopenia.

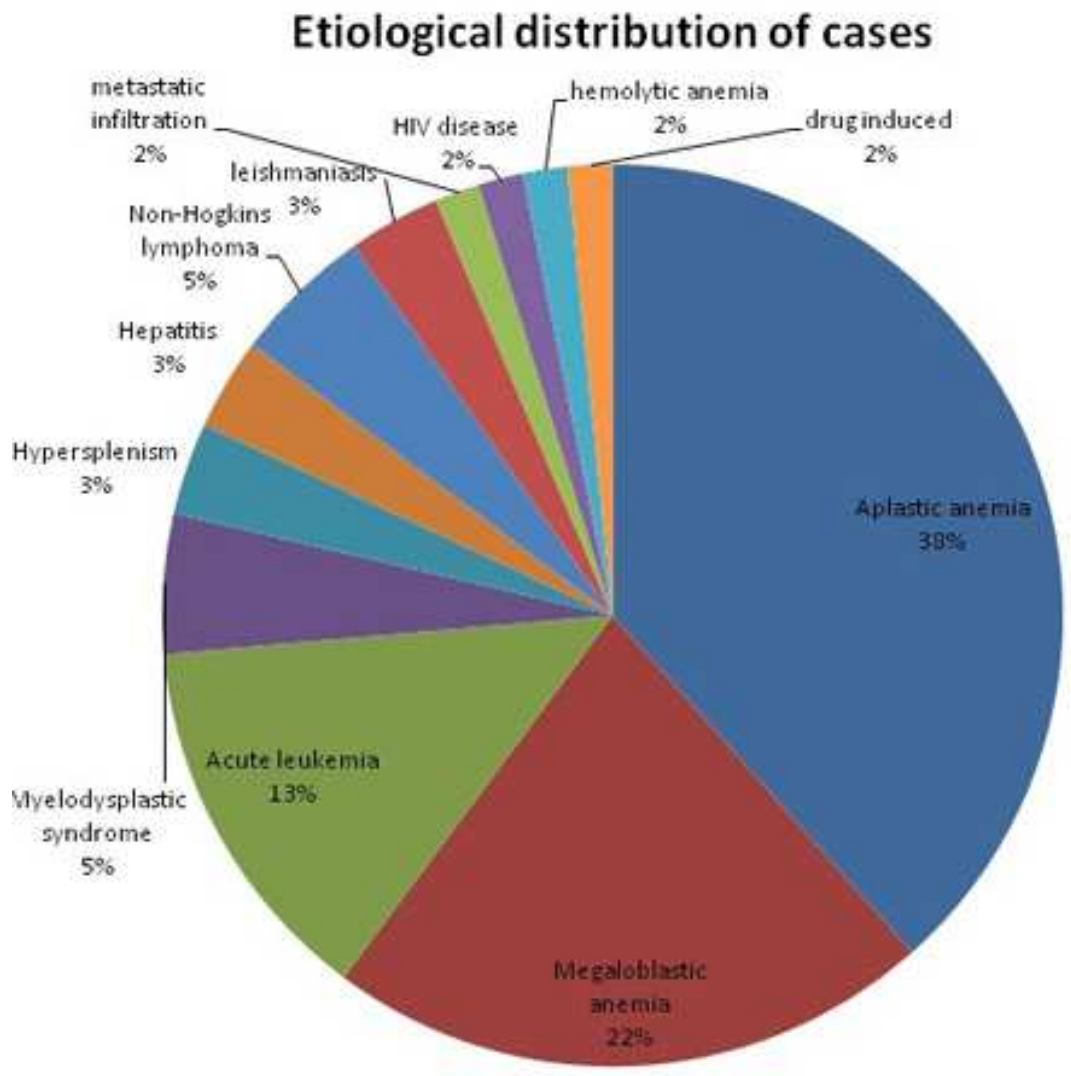

Fig. 2: Etiological distribution of cases with pancytopenia. 


\section{ORIGINAL ARTICLE}

\section{Deficiencies}

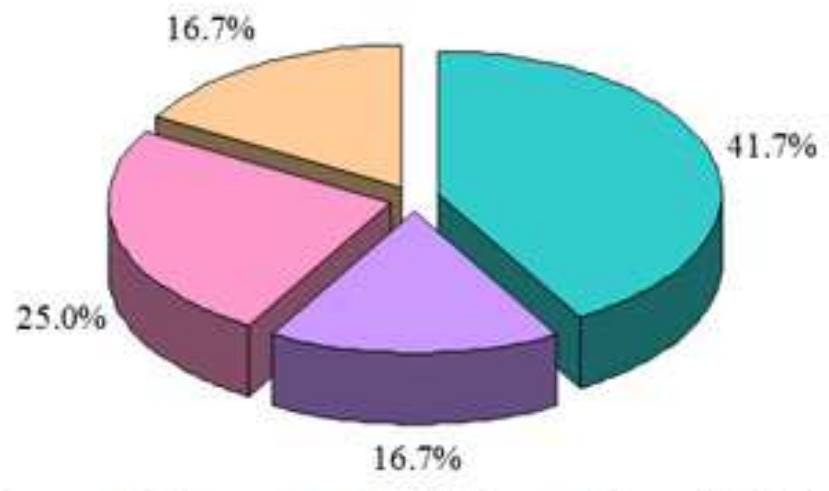

$\square$ B12 $\square$ Folate $\square$ Combined $\square$ Normal B12 and Folate

Figure 3: Distribution of various deficiencies in megaloblastic anemia presenting with pancytopenia. 